Bureau of Standards ( Div. VIII-3)

Department of Commerce, Wasington, D. C.
Letter Circular

Revised July 26, 1920.

SOIRCES OF INFORMATION AND DATA ON THE PROPERTIES OF METALS AND ALICYS.

The Bureau receives many requests for general and comprehensive information on the properties of metals and alloys; general requests of this sori for such a volume of information it is really possible to answer only with a statement of sources where the information may be obtained. This letter circular attempts to give a working bibliography of reference and hancbooks.on this subject. The Eureau itself is preparing circulars dealing with the properties of individual metals and alloys but these are as yet too few to permit a general circular to be based on them dealing with all metals and alloys.

The sources below are arranged topically, the reference books mentioned should be available in any gocd technical or scientific lj.brary. Mechanical properties of such materials are most excellentiy desoribed by standard specifications for the materials such as those of the American Society for Testing Materials.

Dete of

latest

edition

Handbooks of Tables and Constants

(1) 1918 Richards, J. W., METALLURGICAL CALCULATIONS, pts. I, II, and III; McGraw Publishing Co., New York City.

(2) 1918 LiddeiI, D.M., METALLURGISTS' \& CHEMISTS' HANDBOOK; MoGraw-Hill Book Co., Inc., New York City.

(3) 1918 METALS AND ALLOYS; The Metal Industry, London.

4) 1916 SMITHSONIAN PHYSICAL TABLES; The Smithsonian Institution, Washington, $D, C$.

(5) 1916 MECHANICAL ENGINEERS' HANDBOOK; MaGraw-Hill BOOK CO. Ino., New York City.

(6) 1915 STANDARD HANDBOOK FOR ELECTRICAL ENGINEERS; MCGIaW: Hill Book Co., Inc., New York City.

(7) 1914 TABELLES ANNUELLES DE CONSTANTES ET DONNEES NUMERIQUES DE CHEMIE DE PHYSIQUE ET DE TECHNOLOGIE; GauthierVillars, Paris.

(8) 1915 Societe Francaise de Physique, REOUEIL DE CONSTANTES PHYSIQUES; Gauthier-Villars, Paris.

(9) 1912 Landolt-Bornstein-Roth; PHYSIKALISCH-CHEMISCHE TABELIEN; Julius Springer, Bhrlin.

(10) 1911 HUTTE, Bts, I, II, III; Wi Ihem Ernst \& Sohn, BerIin. (11) 1909 Winkeimann, A., HANDBUCH DER PHYSIK, pts, I-II; Johann Ambrosius Barth, Leipzig. 

Statistios

$(12) 2018$

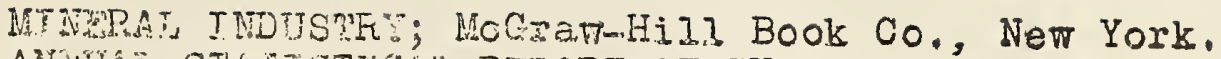

\$13) 1929

AWHOA SIATISTICAZ REPORT OF THE AMERICAN IRON AND

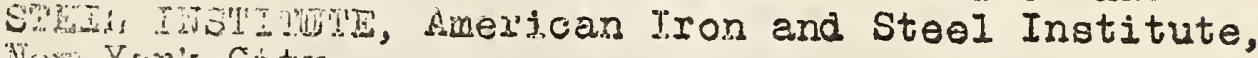
Nex Vors oity.

(14) 1916 U. S. Cadog GeI Survey: MINRRAL RESOURCES OF THE WIITE STGTS; Goveinment Frinting Offlce, Washington, in. 9

(15) 1913 ME⿰冫I SiMTSEICS; Amerioan Metal Market Co., New York Eitiy.

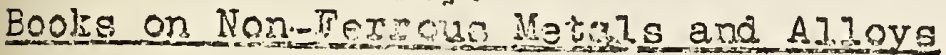

(16) 1920 Bucbanan, J. Fo, PRACTICAI ALLOYING; Penton Publish-

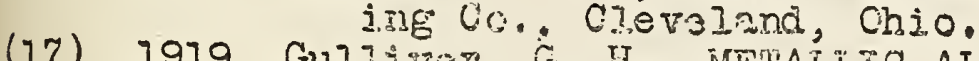

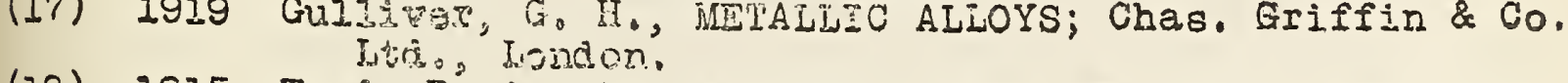

(18) 1915 WOCS, R: A., THE WATERBURY BOOK OF ALLOYS; LaW Print-

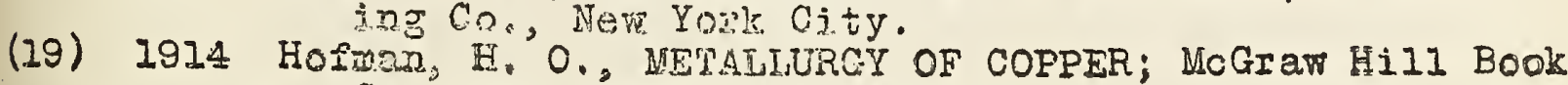

(20) Co., Tnc., Nerr vork City.

(20) 2914 L2W, $E_{0} \Gamma_{0}$ AITOYS AND THEIR INDUSTRIAL APPLICATIOES;

C. Grisin \& Co. Lta., London.

(21) 1914 GUWland, T., NETALITRGY OF NON-FERROUS METAIS; Chas. Gitifin a Go., jucnaon.

(22) 1913 Ledeius, A., DID' LFGIERTITEN; M. Krayan, BerIin.

(23) 1909 Gavediar, J., ALIIAGSS METALIIQUES; Vuibert $\theta t$ Nony; Ratio.

(24) 1909 Krupp, A, DTE IRGERTINGEN; A. Hartleban, Leipzig.

(25) 1908 Broint, W. T, TK METAIIC ALLOYS: Henry Carey Baird \&. Co., Fridizanhia, Da.

(26) 2908 Tust, F.: IECIET-UND LOT-KUNST; Bergin Friedr. Voigt, Leiozig.

(27) 1906 Guille?, L., ETUDE INDUSTRTELIE DES ALLIAGES

(28) 1903 Sack, Hi, BIBIIOGRAPHID DER METALIEGIERUNGEN; L. Voss, Leipsig.

(29) 1901 Hiorrs, A. H, MIXED METALS AND METALLIC ALLOYS; MaC

(30) 1890 Thurston, R. H., A TREATISF ON BRASSES, BRONZES, AIND OTHER ALLOYS AND THEY CGNSTITUENT METALS; JOhn Wiley \& Sons, New York City.

Bookg on Iron and Stel

(31) 1919 Backert, A, 0., THE A B C OF IRON AND STEEL; Penton Irubiz shing Co., CIEveland, Ohio.

(32) 1919 Tiexan, H. P, IF.N AND ST:PI; A Pocket Encyclopedia,

(33) HoGraw-Hili Bool Co., New Vorli Cjsy.

(34) 1918 Bullens, D.K., STEE AND ITS HEAT TREATMENT; John Wiley \& Sons, New Yoris City. 

(35) 1918 Oberg, E, and Jones, F. D., IRON AND STEEL; The Incustrial Press, Nev York Ot tr.

(36) 1917 Spring, I. P., NONWECHNICAI, OHITS ON IRON AND Smit; Frederick A. Stokes So., New York City.

(37) 1916 Harbord and Hal?, THE METSITRSY OF IRON AND STEEL: J. B. Lippincott So., Thijaleinkia.

(38) 1916 Edwards, C. A., PEYSICO-GHWIENA PIOPERTIES OF STEEL; C, Griffiz \& Co.y Ioncsu.

(39) 1915 Giolitti, F., Richards, J." THE CEMENTATION OF IRON AND STEEI; MOGIAW-HiII Book Co., Inc, New York City.

(40) 1912 Mars, G,; DIE SPEZIALSTAHLE; Fercinand Enke,

(41) 1911 Brearley, H, HEAT TREATMENT OF TOOL STEEL;

(42) 1911 Lake, E. F., COLU SITION AIND HEA TREATMENT OF STEEL; MCGSATH H.? RoOl Co., YET York City.

(43) 1910 Haeni,E, A, DER KONSTRLETENS=STLH GND SEINE MTKRO=STRYJTRUR; M. Krann, Beriin.

(44) 1907 Camphell, $\mathrm{H}$. $\mathrm{H}$, THE MANTACTYRE AND PROPERTIES OF

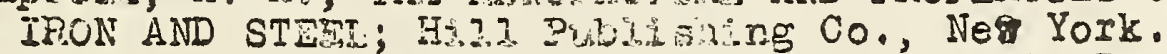

(45) 1904 Guillett, L., IDS ACIERS S.ECIAJX; Ch.'Dunod, Paris. (46) 1903 Howe, H." M., IRON, STEEL AND OTHER ALLOYS; Sauveur \& Whiting, Boston.

(47) 1898 Thurston, R. H, A TREATISE ON IRON AND STEEL; John Wiley \& Sons, Nev York City.

Books on Cast Iron

(48) 1920 Horner, J. G,, PRACTICAL IRON FOUNDING; Sir, Isaac Pittman \& Sons, Lid., London and New York City.

(49) 1918 Hatfield, . H., CAST IRON IN IHE LIGHT OF RECENT RESEARCH; Chas. Gr:ifiln \& Co., Inndon.

(50) 1917 Moldenke, R., THE PRTWCIPLES OR IRON FOUNDING; McGraw Hill Book Co., New York. City.

(5I) 1917 Payne, D. W., THE FUUNDERS MANUAL; D. Van Nostrand \& Co., New York City.

(52) 1911 Kirk, E., FOUNDRY IRONS, H, C. Batid \& Co., Thiladelphia, $\mathrm{Pa}$.

(53) 1911 Geiger, C., HANDBUCH DER EISEN-UND STAHLGIESSEREI; Julius Springer, Berlin.

(54) 1910 Moldenke, R., THE PRODUOIION OF MALLEABLE CASTINGS; Penton Publishing Co.: Cleveland, Ohio.

(55) 1904 Test, T. D., METALIJFGY OF CAST IRON; Oleveland Printing and Fublishing Co, Cleveland, Ohio.

Books on Individual Metals and Metallurgy

Aluminum (56) 1914 Krause, H, DAS ALJMINIUM UND SEINE LEGIERUNGEN; A. Hart1:oher, Leipzig.

(57) 1905 Minet, A., THE FROJUTION OF ALUMINUM AND ITS INDUSTRIAL USE; JOhn Viley \& SOns, NeV York.

Antimony (58) 1909 Wand, C. Y., ANTIMONY; C. Griffin \& Co., London. 


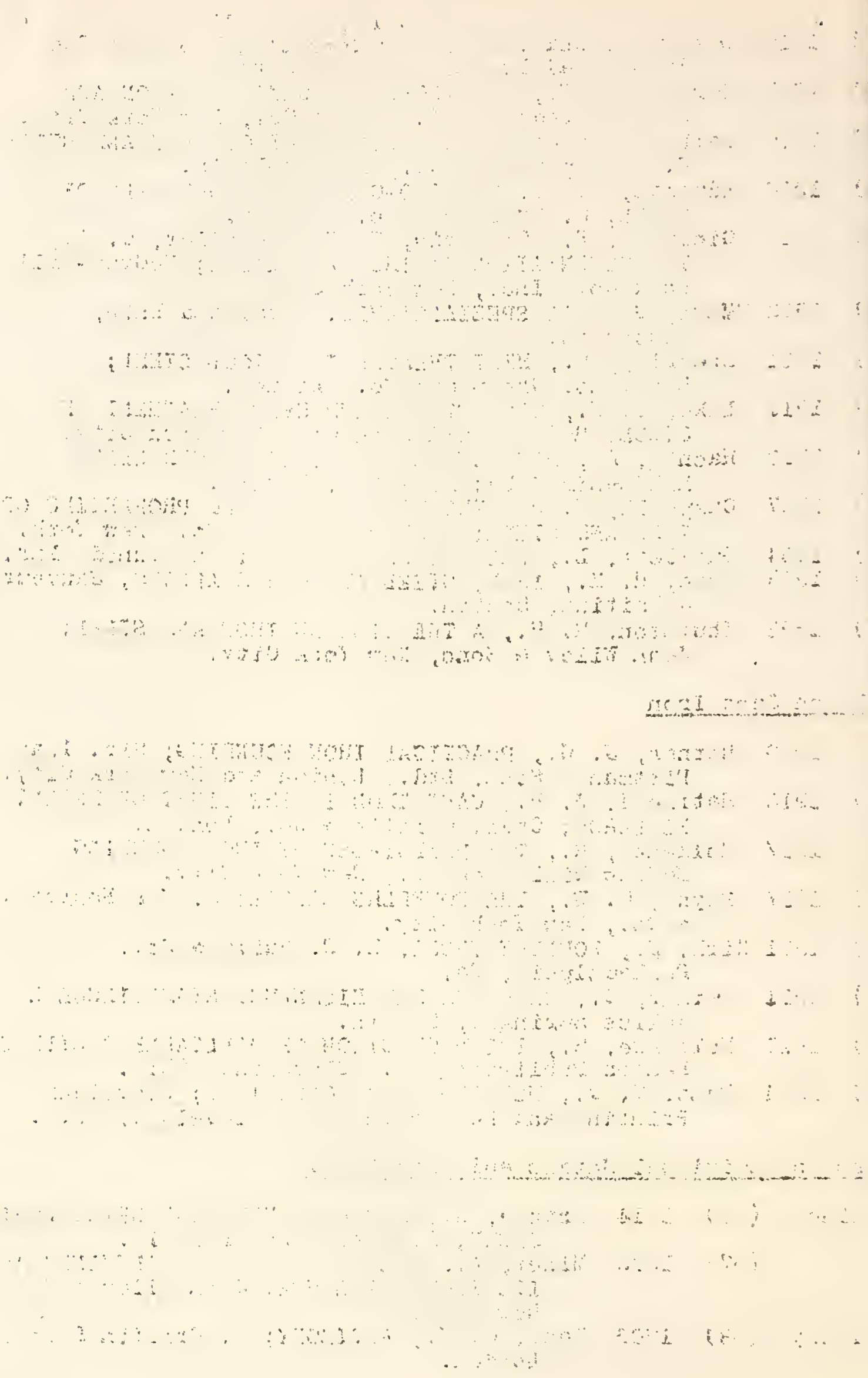


Bi smuth

Cadmium

Cobalt

Copper

Gold

Iron

Lead

Manganese

Mercury

Molybd enum

Niokel

Platinum

Silicon
(59) 1914 Gowland, (21)

1884 Chaxleton, G. At, TIN, ARSENIC, BISMUTH, AND WOLFRAM; E. \& F. Spon, Ltd., London.

(60) 1923 Liebjg, R.G.M.-, ZINC UND CADMIUM; O, Spannex, Leipzis

(61) 1911 Bouchornet, A., ZINO, CADMIUM, CUIVRE, MERCIRE; 0. Doin et fil.s, Paris.

(62) 1910 Ouvard, Y.V.R, INMUTTRTYS DU CHROME, DU MANGAIISE, DU NITKEL ET DU COBALT; 0 . Doin fils, Paris.

1909 Escard, (88)

1914 Gomiand, (2I)

1910 Ouvard, (62)

1914 Hofman, (20)

(63) 1915 Roso, T, R., THE PREQIOUS METALS; D. Van 1914 Gowland, (2I)

(64) 1918 Carnegie, D., LIQUID STEEL; Longmans, Green \& Co., New York City.

(65) 1918 Turner, T., TH: MRALIURGY OF IRON; $c$. Griffin \& Co:, inndon.

1916 Harbord and Hal1 (ir?;

(66) 1918 Hofuan, H. O., METAIJURG OF LEAD; MCGrarHil B Book CO., New York City.

(67) 1910 ColJins, H. F., THE METALLURGY OF LEAD; C. Griffin \& Co., Jondon.

1909 Richter, (80)

(68) 1916 Grosvenor, T. M., MANUFACTURE AND USE OF METALIIC MAGNESIUM; Paper before Amer. Electrochem. Soc. in New York, Feb. 1916

1910 Ouvard, (62)

1909 Escard, (88)

1911 Bowchonnet, (61)

(69) 1916 Horton, F.' T., MOLYBDGivM, ITS ORES, ETC., Government Printing Office, Washington, D. C.

1909 Escard, (88)

1905 Truchot, (74)

(70) 1917 REFORI OF ROYAL ONTARIO NICKEL COMMISSION, A, WiIgress, Toronto.

1914 Gowland, (2I)

1910 Ouvard, (62)

1914 Gowland, (BI)

1912 Molinie and Dietz, (72)

1915 Rose, (63)

(71) 1914 LeChatelier, H., LE SILICE ET LES SILICATES;

A. Hermann et fils, Paris.

1909 Escard, (88) 

Silver

Tin

Titanium

Tungsten

Uranium

Vanadium)

Zinc

(77)

(78) 1913

(79) 1903

(80) 1909

(81) 1905

Zirconium

Genaral
1915 Rose, (63)

1914 Gowland, (21)

(72) 1912 Molinie, M., and Dietz, H., INDUSTRFES DES METAUX PRECIEUX; 0 . Doin et fils, Paris.

Louis, H., METÁILLTRGY OF TIN; MaGrav-HiII Book Co., NeT York.

Richter, (8́)

Truchot, P., LES PETITS METAUX, TITANE, YUNGSTENE, MOLYBDENUM; Gauthier-Villars, Paris.

Menntcke, H., DIE METALLURGIE DES WOLFRAMS; M. Krayn, Berlin.

(76) 1915 Parsons, C,L,, EXTRACTION AND RECOVERY OF RADIUM, URANIUM AND VANADIUM; Government Printing Office, Tashington, D.C.

1909 Escard, (88)

Smith, E.A., THE ZINC INDUSTRY; Longmans Green \& Co., London and NeT York City.

Liebig, R.G.H., ZINK UND CADMIUM; 0 . Spanier, Leipzig.

Ingalis, $\mathrm{T} . \mathrm{R}_{1}$, THE METALLURGY OF ZINC AND CADMIUM; The Engineering \& Mining Journal, Ner York.

Richter, K., ZINK, ZINN UND BLEI; A. Hartieben, Leipzig.

Lodin, M., METALLURGIE DU ZINC; Ch. Dunod, Paris.

(8\%) 2917 Meyer, H.C., THE INDUSTRIAL APPLICATIONS OF ZIRGONIUM; Reprint from Mineral Footo Notes, Footo Mineral Co., Pbiladelphis, Pa.

1915 Johnstone, (83)

(83) 1915 Johnstone, S.J., THE RARE EARTH INDUSTRY; Crosby, Lockwood \& SOn, London.

1914 Gowland, 正, (21)

(84) 1913 Hofman, H.OQ̈, GENERAL METALLURGY; MoGrawHili Book Co., NeW York City.

(85) 1912- ThOTPE, E., DICTIONARY OF APPIIED CHEMIS1913 TRY, 5 volumes; Longmans, Green \& Co., London.

(85) 1905-Abegg, R., and Auorback, Fr., HANDBUCH DER 1913 Anorganischem Chemie; 5 Volumes; S. Hirze1, Leipzig.

(87) 1912 BIowning, P.EF, INTRODUCTION TO THE RARER ELEMENTS; J. Wiley \& Sons, New York.

(88) 1909 Escard, J., LES METAUX SPECIAUX; Dunod et Pinat, Paris.

(89) 1904 Schnabel, C., HANDBUCH DER METALLHUTTENKUNDE; pts. I and II; Julius Springer, Berlin.. 


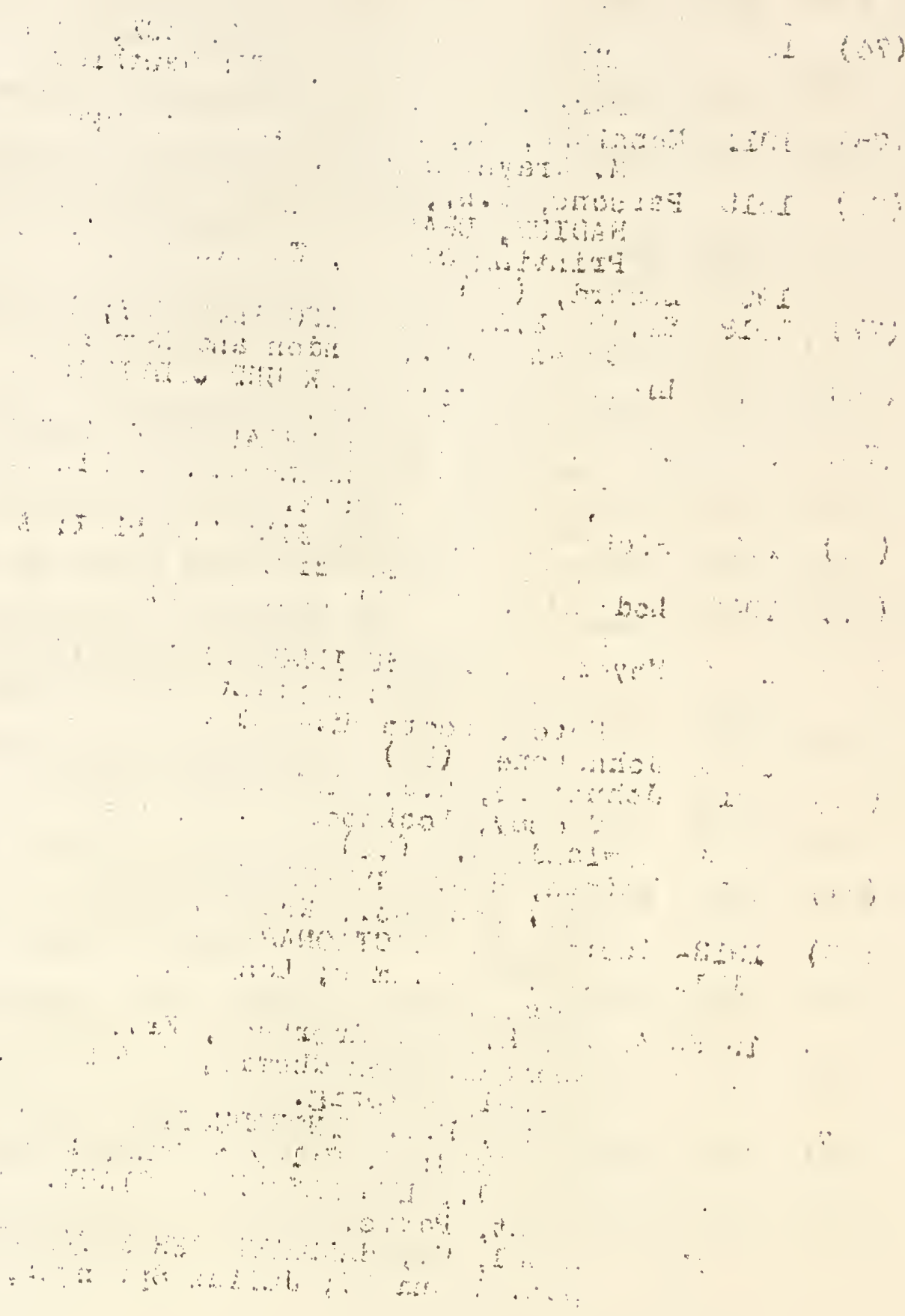


(90) 1920 Hoyt, S, L., PRINCIPLES OF METALLOGRADYY; MoGraw-Hill Book Co., New York Citj.

(91) 1918 Guillet, L. and Portevin, A., PRECIS DE METALLOGRAPHIE MICROSCOPIQUE ET. DE MACROGRAPHIE; H. Dunod et E. Pinat, Paris.

(92) 1918 Sauveur, A., THE METALLOGRAPHY AND HEAT TREATMENT OF IRON AND STEEL; Sauveur and Boylston, Cambridge, Mass.

(93) 1916 HOWe, H. M., METALLOGRAPHY OF STEEL AND CAST IRON; MCGraw-Hill BOOK CO., NeVT York.

(94) 1914 Desch, C.H., METALLOGRAPHY; Longmans, Green \& Co., London.

(95) 1914 Rosenhain, W., INTRODUCTION TO PHYSICAL

(96) METALLURGY; Constable \& Co., Ltd., London.

(96) 1914 Tammenn, G., LEHRBUCH DER METALLOGRAPHIE; Leopold Voss, Leipzig.

(97) 1912-GuertIer, T., HANDBUCH DER METALLOGRAPHIE; 1913 Gebr, Borntrager, Berlin.

(98) 1912 Martons, A., Heyn, E,, MATERIALIENKUNDE FUT DEN MASCHINENBAU; Julius Springer, Berlin.

(99) 1912 Robin, F., TRAITE DE METALLOGRAPHIE; A.

(100) 1909- Bornemann, K., DIE BINAREN METALLEGIERUNGEN; 1912 pts. I and II; Wi thelm Knapp, Halle, A.S.

(101) 1909 Guiliet, L., TREUPE, RECUIT, REVENU, Dunod, et Pinat, Paris.

1909 Cavalier, (2̉3)

(102) 1906 Guiliet, L,, ETUDE THEORIQUE DES ALLIAGES METALLIQUES; Ch. Dunod, Paris.

Speoifications

(103) 1920 SOCIETY OF AUTOMOTIVE ENGINEERS STANDARDS; published through the Standards Manager, Lr. R. S. Burnett, 29 West 39th Street, New York City.

(104) 1920 U. S. NAVY DEPARTMENT SPECIFICATIONS; published through the Bureau of Supplies and Accounts, of the Department.

(105) 1920 U. S. NAVY AERONAUTICAL SPECIFICATIONS; PUBLISHED through the Bureau of Construction and Repair of the Department.

(106) 1920 U. S. ARMY AEROHUTTICAL SPECIFICATIONS; published through the Director of the Air Servioe, War Department.

(107) 1919 American Society for Testing Materials; A.S.T.M. TENTATIVE STANDARDS (see below)

(108) 1918 American Society for Testing Materials; A.S. T.M. STANDARDS, published by the Society through its Secretary-Treasurer, Mr. C.I. Warwick, 1315 Spruce St. Philadelphia, Pa. 

Books on Mechanical Properties

(109) 1920 MOOIE, H. F., TEXT BOOK OF THE MATERIALS OF ENGINEERING; MCGraw-Hill Book CO.; New York.

(110) 1916 Upton, G, B., THE STRUCTURE AND PROPERTIES OF THE MORE COMMON MATERIALS OF CONSTRUCTION; John Wiley \& Sons, New York. 1912 Martens, A., Heyn, E., (98)

Periodicals and Journals.

(111) 1802- TESTS OF METALS; Reports of tests made 1919 at the U.S. Watertown Arsenal, Government Printing Office, Washington, D.C.

(112) 1909- JOURNAL OF THE INSTITUTE OF METALS(BRITISH)

1919 Caxton House, Westminster, S.T.

(113) 1871- JOURNAL OF THE IRON AND STEEL INSTITUTE

(114) 1919 (British) E, \& F, Spon, Ltd. London, 1920 of Mining and Metallurgical Engineers. New York City.

(115) 1895- THE METAL INDUSTRY, 99 John Street, Net 1920 York, Including The Aluminum World, The Brass Founder and Finisher, and The Electroplater's Raview.

(116) 1902 - CHEMICAL AND METALLURGICAL ENGINEERING; 1920 MoGraw-Hill Book Co., New York City. Formetly "Metallurgical and Chemical Engineering" and "Eleotrochemical and Metallurgical Industry" Including "The Me tallographist".

(117) 1881- STAHL UND EISEN; Stahl-eisen m.b.H., 1920 Dusseldorf.

(118) 1904- METALLURGIE; Wilhelm Knapp, Halle, being 1920 now issued as METAL UND ERZ (non-ferrous) and FERRUM (Iron and StreI)

(119) 1904- REVUE DE METALIURGIE; Dunod et Pinat, 1920 Raris.

(120) 1899- PROCEEDINGS OF THE AMERICAN SOCIETY FOR 1919 TESTING MATERIALS; Seoretary-Treasurer,

(121) 1911- INTERNATIONAL ZEITSCHRITT FUR METALLKUNDE; 1920 formerlix "International Zeitschrift fur Metallographie".

Gebr, Borntroeger, Berlin.

(122) 1855- THE IRON AGE; The Iron Age Publishing Co., 1920 New York City.

(123) 1872- THE FOUNDRY; Penton Publishing Co., 1920 Cleveland, Ohio. 

(124) 1915- JOURNAI OF THE SOCIETY OF AUTOMOTIVE 2920 ENGTNEERS. Snciety of Autumotive

Engineers, Ino: Ne York Gity.

(125) 1856- THE ENGTNGE; The Engineex, Iondon. 1920.

(126) 1887 - SCIENTITIG AMRESAN IONTHIY; formerIy

1920 Sojexiti2o Aspion Supiement, Munn \&

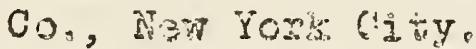

(127) 1897 - PROCTECINGS OF TEE INTRRNATIONAL ASSOCIATION 1912 FOR TESTING MATERIALS; MCGraW-HIII BOOK Co., Ner York.

(128) 1907- CHEMICÁL ABSTRACTS; American Chemical

1920 Sogiety; Es

(129) 1884- ENGINDEINC INDGK: Now published in Mechan1920 ical Engineering, American Society of Mordancal izginerzs, New York City.

(130) 1910- BULTEITIS AND TECINTCAL PAPSRS OF THE 1920 BUREAU OI NINIS; Eureau or̂ Mines, DepartMart of the interior, Washington, D.C.

Bureau of Standarda Pubjicaijons.

\section{SCIEITTEIO PAPERS}

62 Melting points of ironogroup elements by new radiation method; by G, K. Burgess, Apriz 5, 190?.

105 Radiation constants of retals; by $7 . W$. Coblentz, August 22 , 1908.

109 Testing of transformer stee I; by M. G. LIoyd and J. V. S. Fisher, Januery 29, 1809.

120 The thermoelectric properties of tantalum and tungsten; by T. T. Coblentz. Jaruary 15, 1909.

124 Platinum resistance thermometry at high temperatures; by $C$. W. Wajdner and. G. K. Burgess, June 25, 1909.

147 Temperature coefficient of resistance of copper; by J. H. Dellinger, July 13, 1910.

Qlectrioal condiotirity of commercial copper; by F. A. Wolff and J. H. Dalijnger, Aiggrist I, 1910.

Melting points of Isfractory elements; I, Elements of atomic we 2 ght $x$ rex $k g$ to 50 ; by G. $\mathrm{H}$. Burgess and R. G. Waltenberg, April 25, 1913.

Critical ranges $A 2$ and $A 3$ of pure iron; by $G$. $K$. Burgess and J. J. Crowe, September $22,1923$.

Emissivity of metals and oxides; I, Nickel oxide (NiO) in range $600^{\circ}$ to $1300^{\circ} \mathrm{C}$; by G, K. Burgess and P. D. Roote. April 15, 1914.

Specific heat of copper in interval do to $50^{\circ} \mathrm{C}$. , with note on vacuum-jacketed calorimeters; by D. R. Harner $3 d$. May 30, 19is.

Electrical resistance and critical range of pure iron; by G. K. Burgess and I. N. KelIberg, August 2I, 1914. 

242 Emissivity of metals and oxides II; Measurements with micropyrometer; by G. K. Burgess and $R . G$. Viatenberg. Octcoen $24,1914$.

243 Emissivity of metals and oxides: III, Total emissivity of platinum and re?ation betrean total emisgivity and resis tivity; by Paul 10. Foote. January 30, 1915.

245 Temperature coefficient of magnefic permeability within working tange; by Raymond I. Sandford. Jerrusry 30, 1915.

249 Emissivity of metals ard oxides: IV, Iron uxide; by George K. Burgess and Paul D. Foote. June 34.9 .95$.

250 Characteristics of radiation pyrometers; by George K. Burgess and Paul D, Foote! Ausist 10, 1915.

254 Study of quality of platinum ware; by George $K$. Burgess and P.P. D. Sale, August 25, 1915.

266m Preparation of pure iron and iron-carbon alloys, by $f, R$. Cain, E. Schram, and H, E. Gleaves, Fezrivary 29, 1916.

272 Correlation of magnetic and mechenical properties of steel; by Charles W. Burrows. Naruh $29,1016$.

280 Further experiments of volatilization of platinum; by G. K. Burgess and R. G. Wa.Itenberg. June 15, 1916.

294 Freezing point of mercury; by R. M. Wi Inelm. October 26, 1916.

296 Thermoelectric measurement of critical ranges of puse iron; by George K. Burgess and H. Scott. Norember 22, 1916.

300 missivity of Straight and Helical Filaments of Tungsten; by W. W. Coblentz. June 8, 1917.

307 Note on Electrical Conduction in Metals at Low Temperatures; by Francis B. Silsbee. July 33 , 191 .

308 The Reflecting Power of Turgsten and Stellite by 7.7. Coblentz and T. B. Emerson, Auguet 10, 1917.

321 Thermal Expansion of Alpha \& Beta Brass betreen $0^{\circ}$ and $500^{\circ} \mathrm{C}$, in Relation to the Mecinanical Properties of Heterogeneous Brasses of the Muntz Metal Type by Paul D. Merica and L. T. Schad, May $9,1918$.

332 Re Riminary Determination of the Thermal Expansion of Molyb-

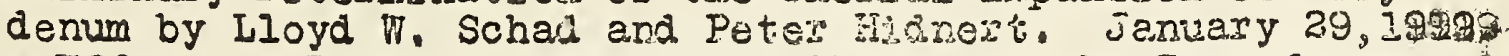

335 The Effect of Rate of Temperature Change on the Transformations in an Alloy Steel, by $H$. Scotit. July $10,1919$.

336 is A Simplification of the Inverse-Rase Method for Thermal Analysis, by P. D. Merica, july 11, 1919.

337 Constitution and Metallogtaphy of Aivminus and its light Alloys with Copper and witb Magnesiur, by P. D. Merica, R. G. Waltenberg and J.R. Freeman, Jr. August 16, 1919.

342 Reflecting Fower of Stellite and Lacquax, Silver, by W. T. Coblentz and H. Kahler. September 11, 1919.

343 Location of Flaws in Rifle-Barrel steel by Magnetic Analysis by R. L. Sanford and Wm. B. Kouxienhoven, Dotobex 3, 1919.

$34 \mathrm{E}$ Oxygen Content by the Ledebur Method of Acid Bessemer Steels Deoxidized in Various Tays, by J.R. Cain and Earl Peti:john. November 11, 1919. 

347 The Heat Treatment of Duralumin, by P. D. Merica, R. G. WaItenberg and $H$. Scott, Novenber 15, 1919.

348 Use of a Modified Rosenhain Furnace for Thermal Analysis by H. Scott and J. R. Freeman, October 24, 1919.

350 Equilibrium Conditions in the System Carbon, Iron oxide, and Hydrogen in Relation to the iedebur Method for Determining Oxygen in Steel, by J. R. Cain, Novercber 10, 1919.

356 Notes on the Microstructure of Iron and Mild Steel at High Temperatures, by Henry S. Ramdon and H. Scott. Merrch 15, 1920.

363 Preparation and Reflective Properties of Some Alloys of Aluminum with Magne sium and with Zinc, by R. G. Waltenberg and W. T. Coblentz. February 12, 1920.

376 Critical Range of Some Commercial fickel Steels, by H. Scott April 6, 1920.

377 Intercrystaline Brittleness of Lead, by H. S. Rawdon. Apri1 6, 1920.

\section{TECHNOLOGIC PAPERS}

11 Comparison of five methods used to measure hardness; Ralph P. Devries. July 22, 1912.

25 Electrolytic corrosion of iron in soils; by Burton MoCollum and K. H. Logan. June 12, 1913.

38 Observations on finishing temperatures and properties of rails; by G. K. Burgess, J. J. Crowe, H. S. Rawdon, and R. G. Taltenberg. April 28, 1914.

53 Investigation of fusible tin boiler plugs; by George K. Burgess and P. D. Merica. October 15, 19.15.

59 Standard test specimens of zinc bronze (Cu 88, Sn10, $\mathrm{Znz}$ ) Part I. - Preparation of specifications; by C. P. Karr. Part II. - Microstructure; by Henry S. Ramoon, March 15, 1916.

60 Microstructural changes accompanying annealing of cast bronze (Cu 88, Sn 10, Zn 2); by Henry S. Rawdon. January 25, 1916.

61 Some foreign specifications for railway materials: Rails, wheels, axles, tires; by G. K. Burgess and P. D. Merica, April $20,1916$.

62 Modern practice in oonstruction and maintenance of rail joints and bonds in electrio railways; by E. R. Shepard, March 10, 1916.

82 Failure of brass: 1, Microstructure and initial stresses in wought brasses of the type 60 per cent copper and 40 per cent zinc; by Paul D. Merica and R. W. Woodward, January 29, 1918.

83 Failure of brass: 2 , Effect of corrosion on ductility and strength of brass; by Paul D. Merica, November 14, 1816.

84 Failure of brass: 3, Initial stress produced by the "burning in" of mangane se bronze; by Paul D. Merica and C. P. KarI November 17, 1916. 

Structure of the Coating on Rinned Sheet Copper in a Specific Case of Corrosion, by Peul D. Merica. dpril 2I, 1913.

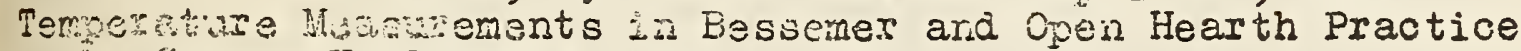

by Ceorge K. Surgess, May 8, 1917.

Some Unicual Features in the Microstructure of Frought Iron

by Henis S。 Rascion. September 20, 1.9!?

01 Tests of Large Bridge Columns, by J,H. Griffith and J.C. Brago, June $27,1918$.

03 Typical Cases of the Deterioration of Muntz Metal (60:40

Bisss) by Selective Corrosion; by H.S. Ramion. December $15,1917$.

og Conservation of Tin in Bearing Metals, Bronzes and Solders; by $G, K$. Burgess and R. W. Toodward. Naroh 15, 1919.

18 A Critical Study of the Ledebur Method for Determining Oxygen in Iron anö Steel; by J.R. Cain and E. Fettijohn. January 11, 1.919 .

31 Strength and Other Properties of Wire Rope; by J. H. Griffith asol J. C. BIagg. July 16, 1919.

A Study of the Coutal Method for Determining Carbon Monoxide and Carbon Dioxide in Steels; by J. R. Cain and Earl Pettijohn. April. 30, 1919.

29 Notes on the GIephitization of White Cast Iron upon Annealing by P. D. Merica and I. J. Gurevich. July I2, 1919.

32 Mechanical Properties and Resistance to Corrosion of Rolled Iight Alloys of Aluminum and Magnesium with Copper, with Nickel and with Manganese; by P. D. Merica, R. G. Waltenberg and A. N. Finn. October 25, 1919.

Behavior of Wrought Manganese Bronze Exposed to Corrosion while under Tensile Stress; by P. D. Merica and R. T. Woodward. October 6, 1919.

39 Some Tests of Iight Aluminum Casting Alloys - The Effect of Heat Treatment; by P. D. Merica and C. P. Karr. October 24, 1919.

41 An Electrolytic Resistance Method for Determining Carbon; by J. R. Cain. December 6, 1929.

43 A Study of the Determwation of Mickel Spark-plug Electrodes in Serfice; by H. S. Rimion and A. I. Krynitsky, January $22,1920$.

56 Metalloganicic Features Revealed by the Deep Etching of Steel; by H.S. Rambu and Samuel Epstein. Hacll 19, 1920.

58 A Peculiar Type of Intercrystalline Brittleness of Copper; by H. S. Rawdon and S. C. Itangdon, fpri2 10, 1920.

63 Stresses Cenzes by Cold ReIIing; by H. M. Howe and E. C. Groesbeck. May 28, 1920. 

CIDCYIAES

7 Pyrometex testing and heat measurements. October $1,1913$.

14. Anamped irous and streels, method of analysis. March 30, 1916.

17 Wagretic testing. Maroh 18, 1916.

31 Copper-wire tables. Cotober 1, 1914.

35 Meling foints of chanical elements. January 1, 1915.

42 Letallographis testing. September 1, 1913.

45 Testing of materials. November 1, 1913.

58 Invar and related nickel steels. April 4, 1916.

70 Waterials for the household. December 5, 1917.

73 Copper \%une 25, 3.918.

76 Aluminury and its Light Alloys. April 21, 1919.

78 Solders for Aluninum. January 28, 1919.

80 Protective Metalijc Coatings for the Rustproofing of Iron and Steel. October 4, 1919.

Nickel and its Alloys (in press) 
4) 15

$\therefore$

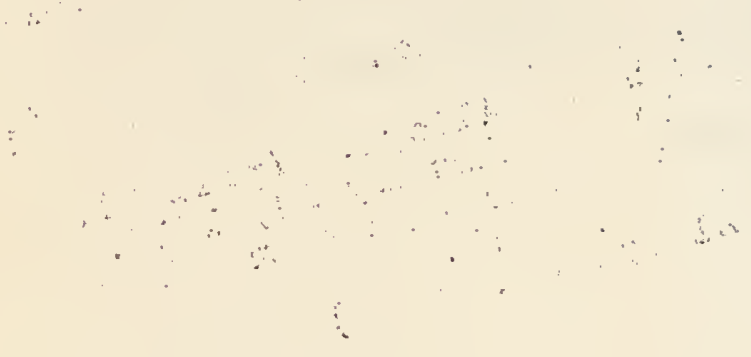

